\title{
Castle Hall Academy: A Case Study In Non-Profit Accounting Mismanagement
}

\author{
Frank J. Grippo, (Email: grippof@wpunj.edu), William Paterson University of New Jersey \\ Noah P. Barsky, Villanova University \\ Joel Siegel, Queens College \\ William Matthews, William Paterson University of New Jersey
}

\begin{abstract}
This case requires you to resolve financial reporting deficiencies that arise in the audit of a notfor-profit entity, a prestigious private high school. This case is based on the actual experience that an audit firm had with a not-for-profit client. The primary reporting issues in the case relate to investments, contributions, severance packages, and leases that arise due to school management's failure to consider recent accounting pronouncements. By completing this case, you will learn about standards that affect not-for-profit entities and how auditors resolve differences with clients. The decisions that you make require an understanding of technical knowledge of topics covered in typical intermediate accounting courses. In addition, the case requires you to integrate accounting theory with the practice of auditing. The premise for the case is that in order to be a successful auditor, you will need a good understanding of your client's business as well as technical accounting issues.
\end{abstract}

\section{INTRODUCTION}

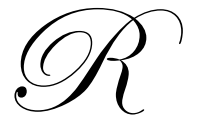

ecent well-publicized crises in the accounting profession have heightened concerns about the overall integrity and reliability of financial statements. Scrutiny and concern have extended beyond SEC registrants. For example, stakeholders in many not-for-profit enterprises are paying greater attention to financial reports. Much of this interest was stimulated by fiscal controversies involving charitable organizations (i.e., the United Way). In response to growing concerns over the clarity of financial reporting for not-for-profit enterprises, the FASB released several pronouncements in recent years.

Most notable, SFAS No. 116 and No. 117 provide authoritative guidance about accounting for contributions (the primary cash inflow for these entities) and the presentations of financial statements, respectively. Many not-forprofit entities hold considerable endowments and invest in special purpose entities. SFAS No. 124 provides guidance regarding how not-for-profit entities should account for such investments.

One difficulty that not-for-profit enterprises frequently encounter is the lack of management personnel qualified to handle complex financial accounting and reporting issues. This operating deficiency is magnified as these enterprises engage in such transactions, often involving considerable dollar amounts. Typically, these enterprises rely heavily on public accounting firms for input and guidance on how to structure and report sophisticated transactions. Jonas and Blanchard (2000) report that auditors are taking on increased responsibility in assessing the quality of clients' reporting choices.

In this case, you will be introduced to several important financial reporting issues that auditors actually encountered when performing the audit for a prestigious private high school. The school benefited from top teachers, a sterling international reputation and extremely generous alumni. However, despite the school's ability to provide full scholarships to all of its students, it suffered from several material financial reporting deficiencies due to an underqualified finance director and the lack of proper oversight. 
You will be assigned to assist the audit team in reconciling reporting differences related to the institution's treatment of its investment in a limited partnership, contributions from alumni, severance payments, and computer leases. These issues reflect matters commonly handled by auditors on not-for-profit engagements.

\section{BACKGROUND}

Castle Hall Academy (the "School") is a prestigious highly competitive New England private high school. It has approximately 560 male students, all of whom receive academic scholarships. Equivalent tuition for such a school would be in the vicinity of $\$ 20,000$ per year. The School has a tremendous academic reputation such that it currently receives about seventeen applicants for every freshman seat. The student faculty ratio is extremely low, and all faculty members are paid salaries competitive with the best public school districts. Its students routinely garner top academic and athletic awards. The institution has excellent teachers who are known to be able to give their students the skills and knowledge to succeed while inculcating a sense of values, ethics, and an appreciation for life-long learning.

Financial viability requires attentive and diligent management. The School's operating expenses are approximately $\$ 7.2$ million annually, which is paid for from annual alumni fund raising, revenues from special events, and investment income from its $\$ 60$ million unrestricted endowment fund. The School has an alumni base consisting of prominent investment bankers, judges, doctors, corporate presidents, PhDs, scientists, and military officers. These people appreciated their education and give back handsomely to the School each year.

\section{Management Structure}

A fifteen member Board of Trustees, all of whom are alumni of the institution, actively supervises the School. These volunteers serve for three year terms during which each member serves on committees for the purpose of advising management concerning plant, investment, finance, technology, fund raising, and personnel issues. Management depends on their acumen when making major business decisions. The synergy between top management and the Board is excellent and has been effective in making the School a respectable academic institution in the region and state. There are four key individuals in management, namely the President, Headmaster, Director of Development, and Director of Finance. The President, Headmaster, and Director of Development are intelligent, polished, well spoken, and experts in their fields. These three individuals are well respected by members of the Board of Trustees, middle management, teachers, and staff. The Director of Finance is another story entirely.

\section{Finance Department}

The Director of Finance, Ken Stanton, is 58 years old, portly, balding, and always disheveled. He dresses in polyester suits with mismatched shirts and ties. He is known as a pleasant person and is eager to please. As a matter of fact, he often says, "yes" and "no problem" to requests that he usually cannot honor. He has been at the School for 30 years and has always been that way. Computers are his real love. He is regarded as knowing everything there is to know about computer hardware and software and has become the "resident technology trouble-shooter" by the teachers and staff. As a result, he has developed a reputation as a computer "guru" and considered invaluable in the eyes of many at the School. Naturally, he spends much time away from his defined job responsibilities doing things like fixing printers, recovering lost files, and fixing viruses.

Recently, the School hired a technology coordinator for their "state of the art" computer lab. Unlike Ken's self-taught, hands-on learning, this person has both academic training and business experience. The School President has instructed employees and students with computer problems to see the new technology coordinator, so Ken can focus on his primary responsibilities, which include supervising his department. The Finance Department consists of three other staff: a general accountant, an accounts payable clerk, and a secretary who performs clerical duties in addition to being a benefits administrator/coordinator. These three individuals are fairly competent, are high school graduates, and have no advanced training in their respective jobs. Their knowledge has basically come from work experience. They have all been with Ken Stanton for at least twenty years and owe their knowledge of their jobs to him. 
The Director of Finance himself has spent too much time learning about computer technology rather than staying current with accounting practices and procedures. Over the years, he has aggravated management and staff alike due to sloppy bookkeeping and lack of attention to detail. Such things as duplicate payments, mispostings to general ledger accounts, payroll errors, and benefit foul-ups have caused a feeling of distrust in his ability. These matters were not customarily brought before the Board of Trustees.

During the 30 years that Ken Stanton has been employed, there have been five School Presidents. None was exceptionally strong in accounting matters. As a result, they relied on Ken Stanton for timely, reliable, and accurate reporting. As long as the School's revenues exceeded expenses, each President was happy. The School's finances consistently produced a surplus due to the success of their investment portfolio (supervised by the Board's investment committee) and excellent annual alumni giving. Thus, the accounting errors remained internal issues that bothered the staff.

Furthermore, Ken was insulated from severe reprimands over the years due to the turnover of Presidents and Headmasters. In addition, the School was not audited, but did receive quarterly compilation statements from a local CPA firm. Ken and his staff were regarded by the outside CPAs as honest, cooperative, and energetic individuals. The CPAs knew of their deficiencies, but corrected the books for gross errors prior to issuing the statements. The Board relied on these statements and did not know that, in effect, the CPAs were compensating for the deficiencies in the Finance Department.

\section{New Ballgame}

The Board of Trustees has been investigating a number of new initiatives including having a $\$ 10$ million capital campaign. A number of members on the Board have extensive accounting and finance backgrounds. One member, a partner in a "Big Four" accounting firm has repeatedly insisted on having an audit conducted for the School. The Board members finally agreed to the recommendations of the Finance Committee and solicited firms to make presentations for performing an audit. A small local firm, Biltmore, Green and Hewlett, was selected to perform the audit and other work such as the preparation of quarterly compilation statements and the Federal Form 5500. The firm has a number of non-profit and school clients and has an excellent understanding of generally accepted accounting principles applicable to non-profits.

\section{Exposed}

Biltmore, Green, and Hewlett prepared an engagement letter, which was promptly signed by the President. The firm agreed to commence the work three weeks after year-end (June $30^{\text {th }}$ ) and issue a report by September $20^{\text {th }}$ as the annual Board of Trustees meeting was scheduled for October $2^{\text {nd }}$. In accordance with Statement on Auditing Standard No. 84, Communications Between Predecessor and Successor Auditors, the firm contacted the predecessor accountants and asked the typical questions. Frank Biltmore met with Alvin Pagano, partner in the office of the predecessor accountants and person responsible for the Castle Hall Academy compilation engagement. Alvin Pagano was very cooperative and helpful and revealed that the business office managed by Ken Stanton tried hard, but was grossly deficient in many areas. He further elaborated and said he thought that the personnel were honest and handled the day-to-day routine transactions well. However, Alvin Pagano felt that Ken Stanton was incapable of preparing financial statements in accordance with GAAP.

After obtaining permission from the client, Pagano allowed Biltmore to review the workpapers. The workpapers revealed that the accountants had to make a number of adjustments so that the financial statements would be properly stated. In addition, it was obvious from the workpapers that the financial statements prepared by Ken Stanton had to be completely revamped. More importantly, however, was the fact that there appeared to be several significant potential accounting issues that were not considered by the predecessor accountants. The explanation by Alvin Pagano was that they were not doing an audit, but merely preparing the compilation statements from the books and records of the company. Furthermore, he stated that these issues were not obvious to them. He felt that by stating in the compilation report that "substantially all disclosures required by generally accepted accounting principles were omitted", the compilation reports were in accordance with standards promulgated by the AICPA. 


\section{The Audit}

In accordance with the engagement letter, on July $21^{\text {st }}$, Frank Biltmore sent Sharon Smith, an experienced audit senior, and a staff person to the offices of the Director of Finance, in order to plan for the audit. As promised, Ken Stanton presented the auditors with a trial balance and interim financial statements that were adjusted to the best of Ken's ability. For the next few days, Sharon Smith and the staff person performed normal planning activities, including, a number of analytical procedures, such as trend analysis, ratio analysis, and explanations of balance sheet changes and revenue and expense variations. An audit program was prepared, and the senior determined the timing, nature, and extent of the work to be done. Special attention was given to the areas of potential problems cited in an internal memo from Frank Biltmore based on discussions with Alvin Pagano and review of the predecessor accountants' workpapers.

Sharon Smith and a staff person worked on the audit for the remainder of July and the whole month of August. During this time, they confirmed the criticisms leveled at the Director of Finance as they found that the bookkeeping was generally sloppy, various differences in bank reconciliations were not adjusted on a timely basis, balance sheet accounts did not tie-in to the detail for those accounts, and many bills were paid without adequate support (i.e., based only on a check request). The lack of attention to this matter by President, Headmaster, and the Director of Development contributed to this breakdown in internal control. Nevertheless, the auditors felt that these problems could be rectified and deemed it their obligation to help establish proper accounting policies and procedures for the School.

The auditors accepted both the inaccuracies and incompleteness of the financial statements prepared by Ken Stanton. They were tolerant of the failure to accrue various liabilities and establish certain accrued income items and prepaid expenses. They did a good deal of substantive testing and, accordingly, made adjustments to various account balances. What surprised them was the fact that the President blindly accepted the monthly internal financial statements prepared by Ken Stanton. He reviewed them and did little questioning concerning unusual items, particularly when the predecessor accountants' external statements differed drastically from the internal financials. Nevertheless, Clancy Smith came to the conclusion that Ken Stanton was incapable of changing and this would be "as good as it gets."

\section{CASE ASSIGNMENT}

Assume that you have been assigned to report to Sharon Smith. Sharon has worked long hours to address the concerns in Frank Biltmore's audit planning memo. He has turned over the audit workpapers to you which include the following items:

- A condensed version of the most recent Statement of Financial Position prepared by Ken Stanton (see Table 1).

- $\quad$ A condensed version of the Statement of Revenues and Expenses (see Table 2).

- A condensed version (summary) of the significant adjusting journal entries prepared by the auditors (see Table 3). These entries recognize year-end accrual items and are consistent with entries prepared by the prior auditor.

- $\quad$ A pledge receivable calculation schedule prepared by Ken Stanton (see Table 4). Sharon Smith tied each of these pledges to source documents to confirm their accuracy, validity, and completeness.

Each of these schedules is available in an Excel file which is available via the Internet at http://www (URL withheld during manuscript review process to maintain author anonymity). Nonetheless, the audit is far from over. The audit workpapers do not yet address four material issues that Sharon Smith wants you to review and analyze. She has an upcoming meeting with Frank Biltmore about the status of the audit and would like your input on the following four outstanding items. 


\section{Gross Misstatements}

Sharon Smith understood Ken Stanton's inability to recognize proper accounting for the following four items as Ken's knowledge of the accounting principles was limited. However, what truly upset her was the failure by the predecessor accountants to reflect these items on their compilation statements. After adjustment, these items would drastically alter the complexion of the financial statements and were material enough to warrant disclosure in the footnotes to the audited financial statements. Each is described below:

\section{Investment in Limited Partnership}

During the year, the School invested in a private limited partnership. The purpose of the partnership was to maximize a return to its partners by participating in private equity and equity-related investments through a diversified portfolio of venture capital, buyout and special situation partnerships, and other limited liability vehicles. The School agreed to a capital commitment of $\$ 2,500,000$. As of June $30,20 \mathrm{X} 3$, the School had invested $\$ 492,097$. Since the fair value of the investment was not readily determinable, in accordance with SFAS No. 124, Accounting for Certain Investments Held by Not-for Profit Organizations, the auditors determined that the School should carry the investment at cost. The $\$ 492,097$ was booked by Ken Stanton in with "Other Assets".

\section{Contributions}

Annual fund, parents' club and alumni contributions represent gifts of cash and securities received during the school year for the purpose of assisting in defraying the operational costs of the School. In accordance with SFAS No. 116, Accounting for Contributions Received and Contributions Made, pledges less an estimated allowance for uncollectible gifts and bequests should be reflected in the financial statements. In 20X2 the School initiated a $\$ 10,000,000$ fund raising campaign to build up resources available to the School and thus ensure its future. Accordingly, contributions which began in $20 \mathrm{X} 3$ under this fund raising program were considered unrestricted gifts. Pledges for the campaign through June 30, $20 X 3$ amounted to $\$ 2,791,300$. In 20X3, the School collected \$504,260 against these pledges. Generally donors will honor their pledges over a five-year period. Pledged gifts and bequests, less an appropriate allowance for uncollectible items, should be recorded at their estimated fair value with amounts due later than one year at the present value of estimated future cash flows calculated using an acceptable discount rate. The auditors determined that $9 \%$ was an acceptable discount rate. The detail of the activity of gifts for the capital campaign from 47 alumni is reflected in Table 4.

\section{Accrued Severance Benefits Payable}

The School has no formal policies regarding severance payments for employees. Rather, such is handled on a "case-by-case" basis. Accordingly, it entered into severance agreements with three faculty members, and agreed to pay these individuals their last year's salary over a period of four years $(20 \mathrm{X} 4,20 \mathrm{X} 5,20 \mathrm{X} 6$ and 20X7). All of these individuals worked during the year ended June $30,20 \mathrm{X} 3$. The detail salary information for the three teachers is as follows:

$\begin{array}{ll}\text { Thomas Minucci } & \$ 64,280 \\ \text { Joseph Miller } & \$ 65,398 \\ \text { Raymond Wilson } & \$ 66,224\end{array}$

In addition, the School entered into a severance benefit agreement with the former Director of Development, Joseph McGuire, who was employed by the School for 25 years and retired on December 31, 20X3. The School has agreed to pay $\$ 20,000$ on June 30 of each year beginning June 30, $20 X 3$ thru June 30, 20X7. Ken Stanton paid the Director of Development $\$ 20,000$ on June 30, 20X1 and charged the payment to salary expense. 
Leased Assets

In June 20X2, the School entered into a major capital lease. The School agreed to lease 140 IBM Thinkpads from Capital Pacific Leasing Corporation at a rate of $\$ 9,804.14$ payable each month for three years. The lease began on July 1, 20X2 and will end June 30, 20X5. Ken Stanton assumed that the lease was an operating lease and recorded the monthly payments to an expense account, "equipment rental". Per review of the lease agreement and underlying documentation, the audit team determined that the lease definitely qualifies as a capital lease. The fair value of the leased equipment was $\$ 311,760$, and the internal rate of interest was $9.00 \%$.

\section{Reluctant To "Sign Off"}

These four issues may have considerable impact on the presentation of the financial statements. Frank Biltmore is reluctant to "sign off" on the audit until each of these issues is fully and properly reconciled.

\section{QUESTIONS FOR DISCUSSION}

1. Evaluate the format and presentation of the financial statements prepared by Ken Stanton. Are they consistent with standards set forth under SFAS No. 117, Financial Statements of Not-for-Profit Organizations? If not, re-format the financial statements and prepare a memo to Sharon Smith identifying your changes.

2. Determine the proper accounting and statement presentation for the Investment in Limited Partnership under SFAS No. 124, Accounting for Certain Investments Held by Not-for-Profit Organizations.

3. Review the Pledge Receivable schedule (Table 4). Based on SFAS No. 116, Accounting for Contributions Received and Contributions Made, what additional calculations are necessary in order to properly account for pledges? Prepare a schedule to support any necessary adjustment.

4. Determine the severance benefit liability at June 30, 20X3 and prepare a schedule to support your adjustment and the amounts to be recorded in the future.

5. Determine the proper accounting and financial statement presentation for the leased equipment. Prepare schedules to support your adjustments. Assume a three year life for the computer equipment with no salvage value. The School's policy is to depreciate all assets on a straight-line basis.

6. Based on your suggested adjustments, update the condensed summary trial balance (Table 5).

7. Prepare a revised Statement of Financial Position and Statement of Revenues and Expenses for the current fiscal year.

8. In your opinion, how should the auditors handle the inadequacies of Ken Stanton? Should they recommend that he be replaced? Why or why not?

9. What is the accountant's responsibility in a compilation engagement? Is it permissible to omit substantially all disclosures in a compilation engagement? 


\section{Castle Hall Academy \\ Balance Sheet \\ June 30, 20X3}

Cash

Assets

Accrued interest receivable

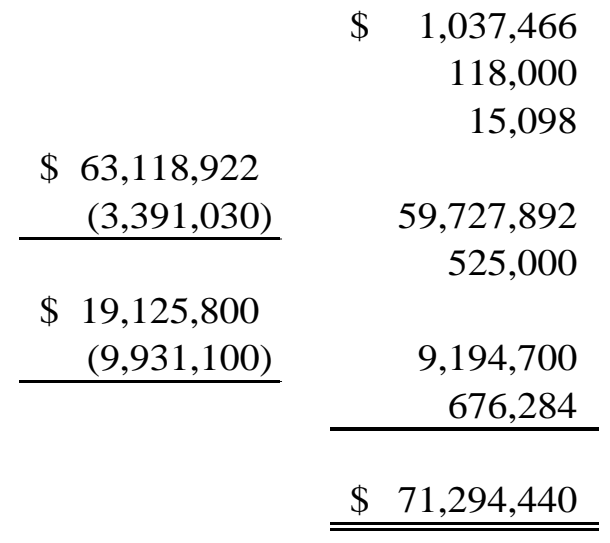

Total Assets

\section{Liabilities and Fund Balance}

Accounts payable

\$ $\quad 78,684$

333,188

Accrued salaries

19,175

Other liabilities

$70,863,393$

Fund balance

\begin{tabular}{rr} 
& $70,863,393$ \\
\hline & \\
$\$ 71,294,440$ \\
\hline \hline
\end{tabular}

Total Liabilities and Fund Balance

$\$ 71,294,440$ 


\section{Castle Hall Academy \\ Statement of Revenues and Expenses \\ For the Year Ended June 30, 20X3}

Revenues and Support

Investment income

Registration and fees

Student activities

Auxiliary enterprises

Special programs

Parents' association

Alumni association

Contributions-Capital campaign

Contributions-Annual fund

Other

Total Revenues and Support

\section{Expenses}

Administration and general

Instruction

Operations and maintenance

Student activities

Auxiliary enterprises

Special programs

Parents' association

Alumni association

Capital campaign expenses

Annual fund expenses

Other

Depreciation

Total Expenses

Excess of Revenues Over (Under) Expenses

$\begin{array}{r}\multicolumn{1}{c}{\text { Actual }} \\ \hline 2,748,325 \\ 15,695 \\ 155,102 \\ 197,455 \\ 45,954 \\ 241,722 \\ 42,845 \\ 504,260 \\ 3,128,578 \\ 211,946 \\ \hline \$ 7,291,882 \\ \hline\end{array}$

$\begin{array}{r}\$ 1,504,226 \\ 3,816,124 \\ 575,073 \\ 302,813 \\ 170,951 \\ 34,752 \\ 37,780 \\ 118,160 \\ 60,010 \\ 505,998 \\ 18,102 \\ 652,000 \\ \hline \$ 7,795,989 \\ \hline\end{array}$

Favorable (Unfavorable) Variance

$\begin{array}{r}\text { Budget } \\ \hline \$ 2,875,000 \\ 17,000 \\ 165,000 \\ 189,000 \\ 39,000 \\ 250,000 \\ 50,000 \\ 750,000 \\ 3,000,000 \\ 226,000 \\ \hline \$ 7,561,000 \\ \hline\end{array}$

$\$(126,675)$

$(1,305)$

$(9,898)$

8,455

6,954

$(8,278)$

$(7,155)$

$(245,740)$

128,578

$(14,054)$

$\$(269,118)$

\$ 75,774

133,876

(10,073)

2,187

4,049

$(2,752)$

$(2,780)$

$(3,160)$

(10,010)

$(5,998)$

$(3,102)$

$(2,000)$

$\$ \quad 176,011$

$\$ \quad(93,107)$ 


\section{Castle Hall Academy \\ Adjusting Journal Entries \\ June 30, 20X3}

Note: For the purposes of this case, the adjustments have been summarized to correspond with the major financial statement account descriptions as indicated on the School's internal financials, Tables 1 and 2. In addition, the numbers have been rounded to the nearest dollar, and adjustments which the auditors made for mispostings and other errors, have been purposely ignored for the case. These entries are similar to the entries made by the predecessor accountants at June 30, 20X2 when they prepared compilation statements as per review of their workpapers.

\begin{tabular}{|c|c|c|c|}
\hline $\mathbf{J} / \mathbf{E} \#$ & Description & Debit & Credit \\
\hline 1 & $\begin{array}{l}\text { Annual fund } \\
\text { General and administration (Bank charges) } \\
\text { Cash } \\
\text { To record bank charges not booked all year } \\
\text { and receipt recorded twice in May. }\end{array}$ & $\begin{array}{r}15,153 \\
1,120\end{array}$ & 16,273 \\
\hline 2 & $\begin{array}{l}\text { Receivables (Contributions) } \\
\quad \text { Parents' association } \\
\text { Alumni association } \\
\text { Annual fund } \\
\text { To record receipts deposited in July, but } \\
\text { applicable to year ended June } 30,20 \mathrm{X} 3 \\
\text { based on subsequent review }\end{array}$ & 60,530 & $\begin{array}{r}3,800 \\
1,550 \\
55,180\end{array}$ \\
\hline 3 & $\begin{array}{l}\text { Other assets (Cash surrender value of } \\
\quad \text { life insurance) } \\
\text { General and administrative (insurance expense) } \\
\text { To record increase in cash surrender value } \\
\text { of life insurance on policy on alumni owned } \\
\text { by the school }\end{array}$ & 8,693 & 8,693 \\
\hline 4 & $\begin{array}{l}\text { Other assets (Inventory) } \\
\text { Auxiliary enterprises expenses } \\
\text { To adjust bookstore inventory to detail }\end{array}$ & 5,500 & 5,500 \\
\hline 5 & $\begin{array}{l}\text { Other assets (Prepaid expenses) } \\
\quad \text { General and administrative (insurance expens } \\
\text { To adjust prepaid insurance to detail }\end{array}$ & 12,228 & 12,228 \\
\hline 6 & $\begin{array}{l}\text { Accrued interest receivable } \\
\text { Investment income } \\
\text { Investment income } \\
\text { Accrued interest receivable } \\
\text { To record interest receivable on bonds in the } \\
\text { investment portfolio and to reverse prior year's } \\
\text { accrual }\end{array}$ & $\begin{array}{l}123,000 \\
118,000\end{array}$ & $\begin{array}{l}123,000 \\
118,000\end{array}$ \\
\hline
\end{tabular}


$7 \quad$ Instruction (salaries)

341,192

Accrued salaries

333,188

Accrued salaries

341,192

Instruction (salaries)

333,188

To adjust accrued salaries payable to detail and to reverse prior year's accrual. [Teachers are paid over twelve months, but work ten months (Sept to June); therefore, two months salaries must be accrued at year end]

8 Administration and general

14,122

Instruction

18,283

Operations and maintenance

9,954

Sutdent activities

1,189

Alumni association

3,428

Expenses-Annual fund

10,130

Expenses-Capital campaign

5,000

Accounts payable

To record additional accounts payable based on subsequent review of payables

9 Operations and maintenance

12,175

Other liabilities

Other liabilities

Operations and maintenance

To record pension liability re: pension plan for maintenance workers and to reverse prior year's accrual not adjusted during the year. This is an annual premium billed in May of each year).

10 General and administrative (Employee benefits)

To record employer's share of TIAA-CREF for the month of June paid in July and not accrued at year end. 
CASTLE HALL ACADEMY

CALCULATION OF PLEDGE RECEIVABLE AUDIT Y/E JUNE 30, 20X3

\begin{tabular}{|c|c|c|c|c|c|c|c|}
\hline $\begin{array}{l}\text { Amount pledged } \\
\text { Amount received during year } \\
\text { Receivable = }\end{array}$ & $\begin{array}{r}2,791,300 \\
(504,260) \\
2,287,040 \\
\end{array}$ & & & Expec & ed Payment & Towards $\mathbf{P}$ & edge \\
\hline Contributors & Pledged & Paid & Balance & $20 \times 4$ & $20 \times 5$ & $20 \times 6$ & $20 \times 7$ \\
\hline Ackerman, Andrew & 25,000 & $(5,000)$ & 20,000 & $(5,000)$ & $(5,000)$ & $(5,000)$ & $(5,000)$ \\
\hline Anderson, Michael & 25,000 & $(5,000)$ & 20,000 & $(5,000)$ & $(5,000)$ & $(5,000)$ & $(5,000)$ \\
\hline Bates, Michael & 5,000 & $(1,000)$ & 4,000 & $(1,000)$ & $(1,000)$ & $(1,000)$ & $(1,000)$ \\
\hline Baker, Joseph & 10,000 & $(2,000)$ & 8,000 & $(2,000)$ & $(2,000)$ & $(2,000)$ & $(2,000)$ \\
\hline Barna, Peter & 15,000 & $(3,000)$ & 12,000 & $(3,000)$ & $(3,000)$ & $(3,000)$ & $(3,000)$ \\
\hline Barba, Joseph & 12,000 & $(2,400)$ & 9,600 & $(2,400)$ & $(2,400)$ & $(2,400)$ & $(2,400)$ \\
\hline Caruso, Robert & 11,300 & $(2,260)$ & 9,040 & $(2,260)$ & $(2,260)$ & $(2,260)$ & $(2,260)$ \\
\hline Carroll, William & 1,000 & (200) & 800 & (200) & (200) & (200) & $(200)$ \\
\hline DeVita, Angelo & 1,000 & (200) & 800 & (200) & (200) & (200) & (200) \\
\hline Dillon, Robert & 150,000 & $(30,000)$ & 120,000 & $(30,000)$ & $(30,000)$ & $(30,000)$ & $(30,000)$ \\
\hline Donlon, Bruce & 500,000 & $(100,000)$ & 400,000 & $(100,000)$ & $(100,000)$ & $(100,000)$ & $(100,000)$ \\
\hline Eagleton, Thomas & 30,000 & $(6,000)$ & 24,000 & $(6,000)$ & $(6,000)$ & $(6,000)$ & $(6,000)$ \\
\hline Edwards, James & 10,000 & $(2,000)$ & 8,000 & $(2,000)$ & $(2,000)$ & $(2,000)$ & $(2,000)$ \\
\hline Engle, James & 10,000 & $(2,000)$ & 8,000 & $(2,000)$ & $(2,000)$ & $(2,000)$ & $(2,000)$ \\
\hline Fallon, Walter & 500,000 & $(100,000)$ & 400,000 & $(100,000)$ & $(100,000)$ & $(100,000)$ & $(100,000)$ \\
\hline Feller, Paul & 750,000 & $(150,000)$ & 600,000 & $(150,000)$ & $(150,000)$ & $(150,000)$ & $(150,000)$ \\
\hline Fenmore, Peter & 25,000 & $(5,000)$ & 20,000 & $(5,000)$ & $(5,000)$ & $(5,000)$ & $(5,000)$ \\
\hline Gallagher, Martin & 20,000 & - & 20,000 & $(10,000)$ & $(10,000)$ & & \\
\hline Griffith, Michael & 5,000 & $(1,000)$ & 4,000 & $(1,000)$ & $(1,000)$ & $(1,000)$ & $(1,000)$ \\
\hline Hawthorne, Steven & 1,000 & (200) & 800 & (200) & (200) & (200) & (200) \\
\hline Holmes, Jonathan & 1,000 & (200) & 800 & (200) & (200) & (200) & $(200)$ \\
\hline Homer, Leroy & 25,000 & - & 25,000 & $(10,000)$ & $(5,000)$ & $(5,000)$ & $(5,000)$ \\
\hline Jefferson, William T. & 20,000 & $(4,000)$ & 16,000 & $(4,000)$ & $(4,000)$ & $(4,000)$ & $(4,000)$ \\
\hline Johnstone, Kenneth & 20,000 & $(4,000)$ & 16,000 & $(4,000)$ & $(4,000)$ & $(4,000)$ & $(4,000)$ \\
\hline Keller, Newton & 10,000 & $(2,000)$ & 8,000 & $(2,000)$ & $(2,000)$ & $(2,000)$ & $(2,000)$ \\
\hline Kovacs, John & 100,000 & $(20,000)$ & 80,000 & $(20,000)$ & $(20,000)$ & $(20,000)$ & $(20,000)$ \\
\hline Kramen, Mark & 500 & (100) & 400 & (100) & (100) & (100) & $(100)$ \\
\hline Lynch, Robert & 10,000 & $(2,000)$ & 8,000 & $(2,000)$ & $(2,000)$ & $(2,000)$ & $(2,000)$ \\
\hline Lyons, John & 15,000 & $(3,000)$ & 12,000 & $(3,000)$ & $(3,000)$ & $(3,000)$ & $(3,000)$ \\
\hline Massey, Edward & 15,000 & $(3,000)$ & 12,000 & $(3,000)$ & $(3,000)$ & $(3,000)$ & $(3,000)$ \\
\hline McDermott, Donald & 20,000 & $(4,000)$ & 16,000 & $(4,000)$ & $(4,000)$ & $(4,000)$ & $(4,000)$ \\
\hline Moulton, Robert & 100,000 & - & 100,000 & - & $(50,000)$ & $(25,000)$ & $(25,000)$ \\
\hline Neves, Arthur & 50,000 & - & 50,000 & $(20,000)$ & $(10,000)$ & $(10,000)$ & $(10,000)$ \\
\hline O'Connor, John & 1,000 & (200) & 800 & (200) & (200) & (200) & $(200)$ \\
\hline Odam, James & 10,000 & $(2,000)$ & 8,000 & $(2,000)$ & $(2,000)$ & $(2,000)$ & $(2,000)$ \\
\hline Paige, Luther & 7,500 & $(1,500)$ & 6,000 & $(1,500)$ & $(1,500)$ & $(1,500)$ & $(1,500)$ \\
\hline Pajak, Edward & 25,000 & $(5,000)$ & 20,000 & $(5,000)$ & $(5,000)$ & $(5,000)$ & $(5,000)$ \\
\hline Powell, Jason & 25,000 & $(5,000)$ & 20,000 & $(5,000)$ & $(5,000)$ & $(5,000)$ & $(5,000)$ \\
\hline Riley, Peter & 10,000 & $(2,000)$ & 8,000 & $(2,000)$ & $(2,000)$ & $(2,000)$ & $(2,000)$ \\
\hline Saez, Edwardo & 5,000 & $(1,000)$ & 4,000 & $(1,000)$ & $(1,000)$ & $(1,000)$ & $(1,000)$ \\
\hline Scully, Thomas & 75,000 & - & 75,000 & $(30,000)$ & $(15,000)$ & $(15,000)$ & $(15,000)$ \\
\hline Steinfield, William & 5,000 & $(1,000)$ & 4,000 & $(1,000)$ & $(1,000)$ & $(1,000)$ & $(1,000)$ \\
\hline Troupe, Robert & 50,000 & $(10,000)$ & 40,000 & $(10,000)$ & $(10,000)$ & $(10,000)$ & $(10,000)$ \\
\hline Ur, Robert & 25,000 & $(5,000)$ & 20,000 & $(5,000)$ & $(5,000)$ & $(5,000)$ & $(5,000)$ \\
\hline Valentino, Albert & 30,000 & $(6,000)$ & 24,000 & $(6,000)$ & $(6,000)$ & $(6,000)$ & $(6,000)$ \\
\hline Vallejo, Charles & 10,000 & $(2,000)$ & 8,000 & $(2,000)$ & $(2,000)$ & $(2,000)$ & $(2,000)$ \\
\hline \multirow[t]{2}{*}{ Velez, Carlos } & 20,000 & $(4,000)$ & 16,000 & $(4,000)$ & $(4,000)$ & $(4,000)$ & $(4,000)$ \\
\hline & $2,791,300$ & $(504,260)$ & $2,287,040$ & $(574,260)$ & $(594,260)$ & $(559,260)$ & $(559,260)$ \\
\hline
\end{tabular}


Castle Hall Academy

Trial Balance Worksheet (Condensed)

June 30, 20X3

\begin{tabular}{|c|c|c|c|c|c|c|c|}
\hline Description & $\begin{array}{c}\text { Unadjusted } \\
\text { Balance } \\
\text { DR }(\mathbf{C R}) \\
\end{array}$ & $\begin{array}{c}\text { Adjustments } \\
\text { Table } 3 \\
\text { DR (CR) } \\
\end{array}$ & $\begin{array}{c}\text { Adjustment } \\
\text { Item \#1 } \\
\text { DR (CR) } \\
\end{array}$ & $\begin{array}{l}\text { Adjustment } \\
\text { Item \#2 } \\
\text { DR (CR) } \\
\end{array}$ & $\begin{array}{l}\text { Adjustment } \\
\text { Item \#3 } \\
\text { DR (CR) } \\
\end{array}$ & $\begin{array}{c}\text { Adjustment } \\
\text { Item \#4 } \\
\text { DR (CR) } \\
\end{array}$ & $\begin{array}{c}\text { Adjusted } \\
\text { Balance } \\
\text { DR (CR) } \\
\end{array}$ \\
\hline Cash & $1,037,466$ & & & & & & \\
\hline Accrued interest receivable & 118,000 & & & & & & \\
\hline Other receivables & 15,098 & & & & & & \\
\hline Investments & $63,118,922$ & & & & & & \\
\hline Allowance for unrealized losses & $(3,391,030)$ & & & & & & \\
\hline Land & 525,000 & & & & & & \\
\hline Buildings, furniture and equipment & $19,125,800$ & & & & & & \\
\hline Accumulated depreciation & $(9,931,100)$ & & & & & & \\
\hline Other assets & 676,284 & & & & & & \\
\hline Accounts payable & $(78,684)$ & & & & & & \\
\hline Accrued expenses & $(333,188)$ & & & & & & \\
\hline Other liabilities & $(19,175)$ & & & & & & \\
\hline Fund balance & $(71,367,500)$ & & & & & & \\
\hline Investment income & $(2,748,325)$ & & & & & & \\
\hline Registration and fees & $(15,695)$ & & & & & & \\
\hline Student activities & $(155,102)$ & & & & & & \\
\hline Auxiliary enterprises & $(197,455)$ & & & & & & \\
\hline Special programs & $(45,954)$ & & & & & & \\
\hline Parents' association & $(241,722)$ & & & & & & \\
\hline Alumni association & $(42,845)$ & & & & & & \\
\hline Contributions-Annual fund & $(3,128,578)$ & & & & & & \\
\hline Contributions-Capital campaign & $(504,260)$ & & & & & & \\
\hline Other & $(211,946)$ & & & & & & \\
\hline Administration and general & $1,504,226$ & & & & & & \\
\hline Instruction & $3,816,124$ & & & & & & \\
\hline Operations and maintenance & 575,073 & & & & & & \\
\hline Student activities & 302,813 & & & & & & \\
\hline Auxiliary enterprises & 170,951 & & & & & & \\
\hline Special programs & 34,752 & & & & & & \\
\hline Parents' association & 37,780 & & & & & & \\
\hline Alumni association & 118,160 & & & & & & \\
\hline Expenses-Annual fund & 505,998 & & & & & & \\
\hline Expenses-Capital campaign & 60,010 & & & & & & \\
\hline Other & 18,102 & & & & & & \\
\hline \multirow[t]{2}{*}{ Depreciation } & 652,000 & & & & & & \\
\hline & - & & & & & & \\
\hline
\end{tabular}




\section{TEACHING NOTES}

\section{Overview}

Castle Hall Academy was developed based on actual audit firm and its relationship with a client. Names of the institution, alumni, management, and the auditors have been change to protect their confidentiality. In a reporting environment where financial statements are under greater scrutiny, this case illustrates to students issues that arise in not-for-profit settings. Although the School has a reputation for quality and a well-funded endowment, an underqualified internal finance team lead to financial statements that are not in accordance with GAAP and may undermine management of the School. The firm performed an audit for the year ended June 30, 20X3 and found a number of accounting problems and gross misstatements relating to (1) investment in a limited partnership, (2) contributions, (3) severance benefits payable, and (4) leases. Instructors should download and distribute an Excel file listed in the case to expedite and standardize student problem solving.

\section{Classroom Use, Results, And Suggestions}

This case introduces students to issues that auditors encounter on not-for-profit engagements. The case requires students to think about how auditors deal with clients with limited financial reporting backgrounds and the implementation for recent not-for-profit pronouncements. This case has been successfully implemented by one of the authors in his Principles of Auditing course at a four-year public university in classes ranging from 20 to 35 students. The case was also given to another professor to implement in his advanced accounting course. This professor commented, "[Castle Hall] does a good job of integrating theory and practice; in addition, it forces the students to think, write, and research the respective pronouncements." The case may also be of use in graduate accounting courses.

The technical components of the case allowed it to be used in a variety of ways. The case was given as a take home assignment, was assigned as a group assignment, and portions of the case were assigned as an in-class component of the cumulative final exam. In the latter situation, the case (without questions) was given to the class to read and study prior to its utilization during the final exam. Data compiled over a number of semesters reveal that generally the students are consistently weak in understanding the importance of present value concepts as one of the integral parts of the solution to the case. When assigning the case, instructors may elect to reinforce the importance of time value of money concepts. Specifically, students should understand that this is one of the most important concepts that a business major learns in college and should be thoroughly familiar with its application. Feedback and grading of the case indicated that some students encountered difficulty in applying the reporting standards of case data.

Nevertheless, their feedback was positive with $85 \%$ of the students giving favorable remarks. Most comments revolved around the case being comprehensive, that it paralleled a real life situation, demonstrated the applicability of technical topics (i.e., time value of money), and combined common sense, accounting theory, and auditing. When the case was discussed in class along with the suggested solution, the students who missed applying present value concepts were upset with themselves because they realized that they were taught this material in previous courses, but for some reason, had trouble applying the theory that they learned. Only $48 \%$ of the students saw the importance of time value of money concepts when preparing the correct journal entries. This feedback suggests that this case is particularly valuable in addressing and reinforcing the importance of technical competencies.

\section{DISCUSSION QUESTIONS AND ANSWERS}

\section{Evaluate The Presentation Of The Financial Statements Prepared By Management.}

Students should be aware of the fact that the presentation of assets, liabilities, and fund balances for not-forprofit enterprises should comply with SFAS No. 117, Financial Statements of Not-for-Profit Organizations. Discussion should evolve around the different types of presentations available. The instructor should emphasize the proper presentation when an entity has unrestricted, temporarily-restricted, and permanently-restricted gifts. This case does 
not have the complications of temporarily restricted and permanently restricted gifts. Rather all contributions are unrestricted in nature. Thus the financial statements are relatively straightforward.

However, the "Balance Sheet" prepared by Ken Stanton is incorrect because it combines Investment in Limited Partnership with Other Assets. This investment should be shown separately under Investments. Other Assets probably include prepaid expenses such as insurance. It also seems to include Cash Surrender Value of Life Insurance. Although these could be broken out and described separately, for the purpose of this case, they can remain in Other Assets due to the lack of available data.

Another important item to mention is the fact that the preferred wording is not "Balance Sheet" as indicated by Ken Stanton, but Statement of Financial Position. Moreover, Fund Balance should not be used. The correct terminology should be Net Assets. In this case, it would all be Unrestricted Net Assets. Furthermore, the instructor should emphasize the fact there should be proper disclosure in the footnotes for policies relating to depreciation and investments. Finally in all likelihood, cash includes items such as certificates of deposit - better wording would be Cash and Cash Equivalents. The Statement of Revenue and Expense is not grossly deficient as it appears to be modeled after a format set up by the predecessor accountants. However, instead of "Excess of Revenues Over (Under) Expenses," the correct terminology is "Change in Net Assets."

\section{Determine The Proper Accounting And Statement Presentation For The Investment In Limited Partnership.}

Since the fair value of the investment is not readily marketable, it would be acceptable to carry the investment at cost. Guidance for the treatment of situations like this can be found in SFAS No. 124, Accounting for Certain Investments Held by Not-for Profit Organizations. However, it is improper to include this item in with Other Assets. It should be shown separately under the Investments account. It also could be combined with the other Investments, but keeping it separate provides better disclosure. Instructors can use this example to discuss the effect of materiality on financial reporting.

\section{Review The Pledge Receivable Schedule (Table 4). Make Calculations Necessary In Order To Properly Account For Pledges. Prepare A Schedule To Support Your Adjustments.}

Pledged gifts should be recorded at their estimated fair value less an allowance for uncollectible contributions. The original schedule show pledges in their gross amounts with no consideration of uncollectible pledges. Amounts due later than one year should be reflected at the present value of the estimated future cash flows calculated using an applicable discount rate. It was stated in the case that the auditors agreed that a $9 \%$ rate was acceptable. Guidance for the treatment of pledges in this manner can be found in SFAS No. 116, Accounting for Contributions Received and Contributions Made. The auditors made the following adjustment in order to properly reflect pledges receivable as an asset (See Table 5):

Pledges receivable

Discount re: pledges receivable

Allowance for uncollectible gifts

Contributions-Capital campaign

$\begin{array}{cr}\stackrel{\text { Debit }}{287,040} & \text { Credit } \\ & 265,018 \\ & 230,000 \\ & 1,792,022\end{array}$


The footnote in the financial statements should be similar to the following:

Contributions receivable before discount factor and allowance for uncollectible gifts:

$\begin{array}{lr}\text { Due less than one year } & 574,260 \\ \text { Due in two years } & 594,260 \\ \text { Due in three years } & 559,260 \\ \text { Due in four years } & \underline{559,260} \\ & \$ 2,287,040 \\ \text { Gross Pledges Receivable } & \\ \text { Less: } & (265,018) \\ \text { Discount factor } & \underline{(230,000)} \\ \text { Allowance for uncollectible gifts } & \underline{\$ 1,792,022} \\ & \end{array}$

Determine The Severance Benefit Liability At June 30, 20X3 And Prepare A Schedule To Support Your Adjustment And The Amounts To Be Recorded In The Future.

Severance benefits are a long-term liability. Accordingly, it should be reflected in the statement of financial position at the present value of estimated future cash flows discounted at an appropriate interest rate. Since the severance benefits relate to services rendered prior to June $30,20 \mathrm{X} 3$, the present value of the payments to be made should be charged to expense in the year ended June 30, 20X3. Using a 10\% discount rate consistent with Item 3 , the auditors made the following adjustment at June 30, $20 \mathrm{X} 3$ (See Table 5)

$\begin{array}{lcc} & \underline{\text { Debit }} & \underline{\text { Credit }} \\ \text { Salaries (Instruction) } & 172,947 & \\ \text { Salaries (Administrative) } & 70,625 & \\ \text { Discount re: severance pay } & 32,330 & \\ \text { Severance payable } & & 275,902\end{array}$

The entries to be made in 20X4, 20X5, 20X6 and 20X7 are shown in Table 7.

Determine The Proper Accounting And Financial Statement Presentation For The Leased Equipment. Prepare A Schedule To Support Your Adjustment.

The case explicitly states that the lease meets the criteria for a capital lease. To qualify as a capital lease, the lease must meet one of four criteria. Specifically, if (1) ownership is transferred at the end of the lease; or (2) there is a bargain purchase option; or (3) the lease term is $75 \%$ of the economic life; or (4) the present value of the lease payments is $90 \%$ of the fair value, the lease must be capitalized. We do not have information re: (1) and (2). There could be a debate about (3). However, there is no debate about (4) as the present value of the lease payments are more than $90 \%$ of the fair value of the computer equipment (See Table 6). Accordingly, the auditors made the following adjustments at June 30, 20X3: 


$\begin{array}{llc}\begin{array}{l}\text { Leased Equipment Under Capital Lease } \\ \text { Obligations Under Capital Lease } \\ \text { To capitalize lease }\end{array} & \underline{\text { Debit }} & \underline{\text { Credit }} \\ \begin{array}{l}\text { Interest Expense } \\ \begin{array}{l}\text { Obligations Under Capital Lease } \\ \quad \text { Equipment Rental }\end{array}\end{array} & 308,372 \\ \begin{array}{l}\text { To correct client misposting } \\ \text { (Monthly payment of \$9,806.14 x 12) }\end{array} & 23,950 & \\ \quad 93,724 & 117,674 \\ \begin{array}{l}\text { Depreciation expense-leased equipment } \\ \text { Accumulated depreciation-leased equipment }\end{array} & \underline{\text { Debit }} & \underline{\text { Credit }} \\ \end{array}$

Furthermore, the footnote to the financial statements should read as follows:

The School has entered into a capital lease for computer equipment. Aggregate minimum annual rentals at June 30, 20X3 are as follows:

\begin{tabular}{lc}
$\underline{\text { Fiscal Year }}$ & $\underline{\text { Amount }}$ \\
\hline $20 X 4$ & $\$ 117,674$ \\
$20 X 5$ & $\underline{\$ 17,674}$ \\
Total Minimum Rentals & $\$ 235,348$ \\
Less-Imputed interest @ 9\% & $\underline{(20,699)}$ \\
$\quad$ Present Value of Net Minimum & $\$ 214,649$ \\
Lease Payments & \\
Less-Amount of Net Minimum & $\underline{(102,516)}$ \\
Lease Payments due in one year & \\
Present Value of Net Minimum Lease & $\underline{\$ 112,133}$ \\
Payments due after one year
\end{tabular}

\section{Complete The Condensed Summary Trial Balance For The Auditor Adjustments.}

This is illustrated in Table 7. The auditors' adjustments in Table 3 should be summarized and posted to Table 7. The instructor may want to review each of these accruals and discuss the financial statement effects of each.

Prepare A Revised Statement Of Financial Position And Statement Of Revenues And Expenses.

As illustrated in Tables 8 and 9, these statements are drawn from the adjusted trial balance. Note the change in wording from "Statement of Revenues and Expenses" to "Revenues, Support, Expenses and Change in Net Assets."

\section{In Your Opinion, How Should The Auditors Handle The Inadequacies Of Ken Stanton? Should They Recommend That He Be Replaced?}

Auditors are not necessarily reluctant to make such recommendations. However, there are important tradeoffs. Ken Stanton definitely is not the best accountant. He does have some good attributes, namely loyalty, honesty, work ethic, and a positive attitude. A better approach is to develop an understanding of his shortcomings, discuss such 
with him in a frank and honest way, and try to make modest improvements. Better controls should be instituted and lines of communication developed so that some of the accounting issues can be handled before the year-end audit. Since compilation statements are prepared by the auditors on a quarterly basis, they should keep abreast of potential accounting issues on an interim basis. This will have the added advantage of a more efficient and thorough audit. The School should not expect a high quality CFO unless they offer a market salary. Such issues stimulate interesting classroom discussion.

What Is The Accountant's Responsibility In A Compilation Engagement? Is It Permissible To Omit Substantially All Disclosures In A Compilation Engagement?

The responsibility of an accountant in a compilation engagement is to present data supplied by the client in a financial statement format without expressing any type of assurance that there are any material modifications that should be made for the financial statements to conform to GAAP. It is permissible to omit substantially all disclosures in a compilation engagement as the predecessor auditors did in the case, but the compilation report must indicate that the disclosures are omitted. 


\section{CASTLE HALL ACADEMY \\ CALCULATION OF PLEDGE RECEIVABLE AUDIT Y/E JUNE 30, 20X3}

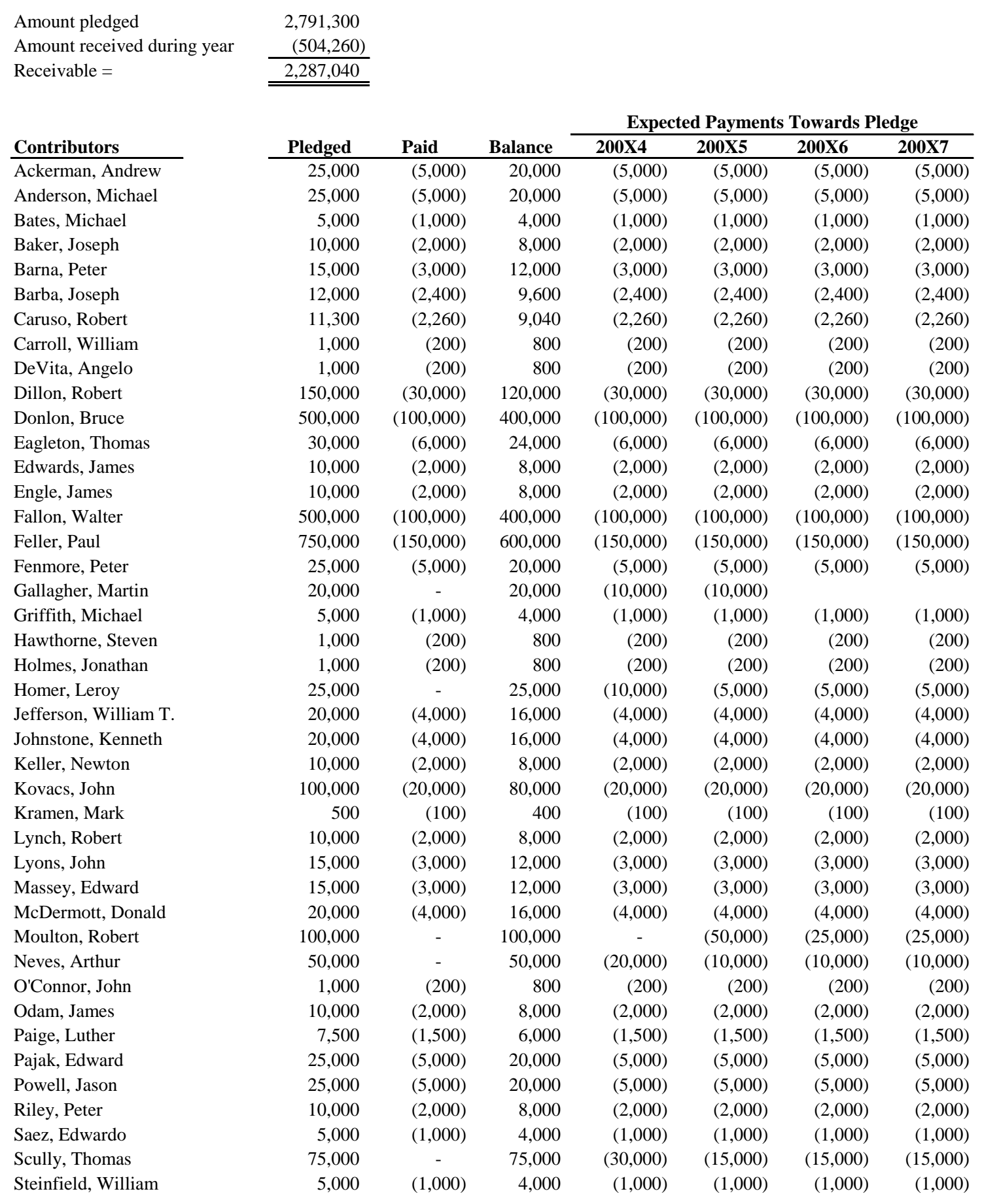


@ 06/30/X3

(2)

@ 06/30/X4

@ 06/30/X5
1 Leased Equipment Under Capital Lease Obligation Under Capital Lease

2 Interest Expense

Obligation Under Capital Lease

Cash

3 Depreciation Expense

Accum Deprec-Leased Equipment

4 Interest Expense

Obligation Under Capital Lease

Cash

5 Depreciation Expense

Accum Deprec-Leased Equipment

6 Interest Expense

Obligation Under Capital Lease

Cash

7 Depreciation Expense

Accum Deprec-Leased Equipment
$308,371.77$

(308,371.77)

23,949.94

$93,723.74$

$(117,673.68)$

$102,790.59$

(102,790.59)

$15,158.00$

$102,515.68$

$(117,673.68)$

$102,790.59$

$(102,790.59)$

$5,541.32$

$112,132.36$

$(117,673.68)$

$102,790.59$

$(102,790.59)$

\section{REFERENCES}

1. Financial Accounting Standards Board. SFAS No. 116 Accounting for Contributions Received and Contributions Made. Norwalk, CT.

2. $\quad$----.-. SFAS No. 117 Financial Statements of Not-for-Profit Organizations. Norwalk, CT.

3. $\quad$---or SFAS No. 124 Accounting for Certain Investments Held by Not-for-Profit Organizations. Norwalk, CT.

4. Jonas, G. J. and J. Blanchet. 2000. Assessing the quality of financial reporting. Accounting Horizons 14 (September): 353-363. 


\section{NOTES}

